\title{
Academic achievement and the effects of the student's learning context: a study on PISA data
}

\author{
Mayra Antonelli-Ponti \\ Patrícia Ferreira Monticelli \\ Fabiana Maris Versuti ${ }^{\top}$ \\ Josiane Rosa Campos ${ }^{2}$ \\ Luciana Carla dos Santos Elias ${ }^{1}$ \\ ${ }^{1}$ Universidade de São Paulo, Ribeirão Preto, Brasil \\ ${ }^{2}$ Universidade Estadual Paulista, Bauru, São Paulo, Brasil
}

\begin{abstract}
School achievement is under a multiple factorial context related to student, school and family (SSF). Based on 23.141 Brazilians self-reports, obtained from PISA 2015, representative SSF measures were selected, and their impacts measured on school performance scores in mathematics, reading and science. The feeling of belonging to the school (BELONG) and parents' emotional support (EMOSUPS) were strongly correlated with the three investigated performances. EMOSUPS affected how the student feels at school and when being assessed. And the educational and cultural resources of the home affected EEC three dimensions, increasing EMOSUPS, BELONG and school performance, and decreasing anxiety during assessments. Thus, the importance of the school and family environments on students' performance is reiterated and calls for public policies in education that considers the three dimensions.

Keywords: school environment; education; family; social bond; companies.
\end{abstract}

Desempenho Escolar e Efeitos do Contexto de Aprendizagem do Estudante: Um Estudo sobre os Dados do PISA

\section{Resumo}

O desempenho escolar está sujeito a um contexto de múltiplos fatores, relacionados ao estudante, escola e família (EEF). A partir de autorrelatos de 23.141 brasileiros, obtidos do PISA 2015, foram selecionadas medidas representativas de EEF e medidos seus impactos sobre escores de desempenho escolar em matemática, leitura e ciências. Registrou-se forte correlação entre a sensação de pertencimento à escola (BELONG) e suporte emocional da família (EMOSUPS) com os três desempenhos investigados; o EMOSUPS teve efeito sobre como o estudante se sente na escola e quando é avaliado; os recursos educacionais e culturais do lar afetaram as três dimensões de EEC, no sentido de aumentar o EMOSUPS, BELONG, e os desempenhos escolares e diminuição da ansiedade durante avaliações. Reitera-se assim a importância do ambiente escolar e da família sobre o desempenho dos estudantes, e a necessidade de essas dimensões serem alvo de políticas públicas na área da educação.

Palavras-chave: ambiente escolar, educação, família, laço social, sociedades

Rendimiento escolar y efectos del contexto de aprendizaje del estudiante: un estudio sobre los datos del PISA

\section{Resumen}

El rendimiento escolar se comprende bajo un contexto factorial múltiple, relacionado con el estudiante, la escuela y la familia (EEF). Con base en 23.141 autoinformes de brasileños, obtenidos del examen PISA 2015, se seleccionaron medidas de EEF representativas y se midieron sus impactos en los puntajes de rendimiento escolar en matemáticas, lectura y ciencias. El sentimiento de pertenencia a la escuela (BELONG) y el apoyo emocional de los padres (EMOSUPS) se correlacionaron estrechamente con los tres desempeños investigados. El EMOSUPS influyó en cómo se siente el estudiante, tanto en la escuela como cuando está siendo evaluado. Los recursos educativos y culturales del hogar afectaron a las tres dimensiones del EEC, aumentando el EMOSUPS, BELONG y el rendimiento escolar, y disminuyendo la ansiedad durante las evaluaciones. Ante estos resultados, se reitera la importancia del entorno escolar y familiar en el rendimiento de los estudiantes y la necesidad de que las políticas públicas en educación consideren estas tres dimensiones.

Palabras clave: ambiente escolar; educación; familia; vínculo social; sociedades

\section{Introduction}

The academic achievement of Brazilian students has been measured by different national educational assessments, such as Provinha Brasil, Prova Brasil and the National Literacy Assessment (Avaliação Nacional de Alfabetização - ANA). These assessment policies take into account not only the students' performance, but, above all, the current educational system and its effectiveness. Among the international assessments, the Programme for International Student Assessment (PISA) stands out, applied in different countries and which, with each edition, improves the ways of accessing the performance of students as well as their personal, 
family and school profiles. The results of the analysis of the PISA databases are published through reports and publications in several areas and themes (Fernández, Rios \& Marques, 2016; Lynn et al., 2017; Pizarro \& Junior, 2017). As the PISA provides a standardized measurement of variables and a good representative sample of the national context, it is constituted as an opportunity to deepen the understanding of the relationship between variables related to the student, school and family (SSF) on school performance.

Educational achievement measures are widely used as predictors of future success (Curi \& MenezesFilho, 2014; Lynn, Antonelli-Ponti, Mazzei, Da Silva \& Meisenberg, 2017). Multiple factors can influence school performance, among them stand factors related to the student itself, their school context and their family environment (SSF). Genetic and epigenetic factors collaborate in the expression and development of cognitive and social skills throughout life (Briley et al., 2018); the student's level of anxiety and their sense of well-being is related to their grades in the assessments (Gonzaga, Silva \& Enumo, 2017; Stein \& Nesse, 2015; Steinmayr, Crede, McElvany \& Wirthwein, 2016); the student's level of curiosity and responsiveness to take initiatives, and their tendency to engage in individual and group activities collaborate with his performance at school (Fogaça, Tatmatsu, Comodo, Del Prette \& Del Prette, 2019); and on the other hand, impulsiveness, distraction, the inability to postpone gratifications, and the readiness to resort to aggression and violence are disruptive characteristics that can hinder educational relationships and achievements (Campos, Silva, Zanini \& Loureiro, 2019; Fogaça et al., 2019).

From the perspective of Biology, the development of a young person takes place within a socio-cultural context created over a history of thousands of years of primate evolution (Tooby \& Cosmides, 1989). The bioecological model of human development emphasizes the importance of a context on the life cycle, considering that all developmental results are a joint function of the person's characteristics and the proximal processes that they establish in the environments in which they live: development is considered systemic and dynamic, subject to multiple trajectories (Bronfenbrenner \& Morris, 1998). Early in the social life of the individual, as much so today as it was eight thousand years ago, are the parents (or primary caregivers, regardless of the family model), which establish the first physical and emotional relationships and present the young person to the practices which are valued in their socio-cultural environment (Ainsworth, Blehar, Waters \& Wall, 2015; Silva, Constantine \& Rondini, 2012). Throughout the development, changes in relationships and roles occur (Cole \& Cole, 2004) and, from the early teens, we see the emergence of a need to distance themselves from family and to belong to a new social group, which may become that which is found in school (Bjorklund \& Pellegrini, 2002).

The effects of the family environment on the socio-cognitive and emotional development of young people are reiterated in the literature over time (Alves, Lemos, Brito, Martins \& Almeida, 2016; Baharudin, Hong, Lim, \& Zulkefly, 2010; Bjorklund \& Pellegrini, 2002; Castro et al., 2015; Silva, et al., 2012). The "creative environment" involves the kind of emotional and affective support that the young person receives, the presence or absence of a family routine, the material structure of nourishment and housing (Erbeli, Hart \& Taylor, 2018; Kong et al., 2018). These factors jointly influence school performance (Erbeli et al., 2018).

Parents (or family) who invest time and energy in their children, meeting the demands of their development process, nurture the feeling of belonging to the group and of being welcome (Macarini, Martins, Minetto \& Vieira, 2010). This investment in the biopsychosocial development of young people involves behaviors of caring, educating and promoting the development of skills and competences, which include educational parenting practices. These practices, when positive, involve the proper use of attention, the monitoring of school activities (Bolsoni-Silva \& Fogaça, 2018; Gomide, 2014) and the development of actions that promote the development of values, such as responsibility, justice, empathy and generosity. When negative, they are characterized by negligence, lack of attention, lack of affection, relaxed discipline, physical abuse, inconsistent punishment, negative monitoring (Gomide, 2014; Macarini et al., 2010).

Parental monitoring has been linked to academic performance indicators (Baharudin et al., 2010; Hill \& Tyson, 2009; Wang \& Sheikh-khalil, 2014), social competence (Taylor, Conger, Robins \& Widaman, 2015) and resilience (Cabrera-García, Aya-Gómez, MuñozGómez, Guevara-Marín, \& Cano-Rodas, 2016). It can be seen as a measure of how much parents know, strive and encourage their children in educational aspects. This measure also depends on the children's willingness to share information with their parents (Cabrera-García et al., 2016). Young people submitted to negative educational parenting practices, which lacked monitoring 
by the family, were also the most undisciplined, had behavioral/emotional problems (Gomide, 2014) and poor school performance (Sapienza, Aznar-Farias \& Silvares, 2009).

The relationships between parental support/ encouragement linked to families' cultural issues, as found in empirical results, show strong association between good school performance and "high expectations of parents" in relation to their children's studies, with "communication about school issues" and "promotion of reading habits" (Castro et al., 2015). In the North American study by Wang and Sheikh-khalil (2014), with a total of 1,056 adolescents aged 15 to 17 from ten public schools, the participation of parents within the school, with homework and school socialization of their children predicted the academic success and good emotional health of young people, directly and indirectly. Children of parents who valued education and discussed future plans had better school performance. Indirectly, children of parents who helped them to engage and feel like they belonged at school, achieved better school performance.

Finally, the school context that affects performance includes teacher training (Prates, Lima \& Ciasca, 2016), the pedagogical and political project and the curriculum (Dessotti \& Dessotti, 2015), the climate (Melo, 2017), the physical structure of the school (Miranda, Pereira \& Rissetti, 2016), the teacher-student relationship (Campos et al., 2019; Pezzi \& Marin, 2017), among others. The bioecological approach to human development establishes the importance of the school in the development of the student, as a context of the life cycle, since it is where young people spend two decades of their lives (Bronfenbrenner \& Morris, 1998). A school environment in which group relationships do not confer a sense of belonging (in other words, personal security) can generate, in pre-teens and adolescents, chronic anxiety, feelings of worthlessness and behavioral difficulties that will have an effect on their school performance (Mendes, Nascimento \& CostaLobo, 2018).

Thus, this study sought to investigate the impact of SSF variables - namely: the degree of student anxiety in carrying out educational tests (ANX); the degree of the student's sense of belonging at his school (BELONG); the way the student feels emotionally supported by his family (EMOSUPS) and the educational and cultural environment in the student's home (HOMEPOS) - on school performance in mathematics (MATH), reading (READ) and science (SCIE), based on data from 23,141 Brazilians, obtained from PISA/2015. We intend to collaborate with discussions on the integral development of the student by investigating the relationship between academic performance and learning context that is constituted simultaneously by those three dimensions. The identification of these interactional paths can assist in directing future interventions at different levels of national public policies.

\section{Method}

The data used in this study belong to the database of the Programme for International Student Assessment (PISA) 2015. This assessment is carried out every three years in countries that make up the Organization for Economic Cooperation and Development (OECD) and others, such as Brazil, agree to participate in the program. Seventy countries participated in the 2015 edition (35 OECD members and 35 partner countries).

\section{Participants}

The study had a sample of 23,141 students aged between 15 years and two months to 16 years and three months old at the time of the evaluation, enrolled in Brazilian schools in all 27 Brazilian states that participated in the PISA/2015. The sample is predominantly composed of female students $(51.50 \%)$, enrolled in high school $(77.70 \%)$, from schools in the state education system $(73.80 \%)$, based on information extracted of publications by the National Institute of Educational Studies and Research Anísio Teixeira (INEP, 2016).

\section{Instruments}

With regard to the student, we selected the variables ANX and BELONG for the student's degree of sense of belonging to the school; and to investigate the family context, EMOPSUS AND HOMEPOS. Reading performance (READ), mathematics (MATH) and science (SCIE) were assessed through questions that seek to understand the students' learning levels in each subject. Questions related to the profile of the students, their schools and their families were obtained through questionnaires answered by the students themselves. Three performance variables were used, MATH, READ and SCIE. The values assigned to them do not directly correspond to the student's performance. They are scores generated by a statistical analysis procedure (plausible values) which assigns values to each question answered in a student's 2015 PISA test (INEP, 2016). The procedure takes into account the response profile 
to add values that approximate a likely response. The variables are described below.

Mathematics (MATH). The assessment of performance in mathematics, based on three correlated aspects: 'mathematical processes', which describe what individuals do to connect the context of a problem with mathematics to solve the issue; the 'mathematical content', which involve theories and formulas; and the 'context' in which the content is inserted, in other words, the connection between mathematics and realworld situations.

Reading (READ). The assessment of reading performance, based on the following characteristics: 'situation', which refers to the range of contexts or broad purposes to which reading is applied; 'text', referring to the materials read; and 'aspect', which refers to the cognitive approach of involving readers with the text.

Sciences (SCIE). The evaluation of performance in science, based on four components: 'contexts', situations related to personal, national and global location; 'competencies', involving scientific explanation of phenomena, interpretation of data and scientific evidence, evaluation and planning of scientific investigations; 'attitudes', referring to interest, valuing scientific research and environmental responsibility; and 'knowledge', which evaluated concepts and procedural and epistemological contents about science.

Anxiety (ANX). Students assessed their level of agreement with five statements such as "I get very tense when I study for a test" and "I worry that I will get poor grades at school" on a four-point scale between "strongly agree" and "strongly disagree".

Feeling of belonging to the school (BELONG). The students assessed their level of agreement with six statements such as "I feel I belong at school", "Other students seem to like me" and "I feel just like myself at schoop" on a four-point scale between "strongly agree" and "strongly disagree".

Emotional support from the family (EMOSUPS). Students assessed their level of agreement with four statements such as "My parents are interested in my school activities" and "My parents encourage me to be confident" on a four-point scale from "strongly agree" to "strongly disagree".

Educational and cultural resources present in the home (HOMEPOS). Index of household goods and educational and cultural resources present in the home, built from student responses to 44 items on what they have in their home environments, such as:
"A quiet place to study"; "Books of poetry"; "A computer you can use for schoolwork"; "A dictionary".

Procedure

We performed an exploratory study of the PISA database, available at the OECD website (http://www. oecd.org/pisa/data/). Among the variables resulting from the responses of students, family members of students, teachers and school principals, we only selected the responses self-reported from students, which provide measures of educational performance and the SSF learning context.

\section{Data analysis}

To obtain the selected variables in the PISA database, the International Database Analyzer (IDB) statistical program was used. An average of the values obtained by students from 27 Brazilian states was generated for each of the variables investigated. For each state, the sample was subdivided according to gender (M: male; F: female) and grade (Modal - Md: students in the expected grade for their age, Non-modal - NMd: students out of the expected grade for age), in which the student was enrolled at the time of assessment. Considering the total of 27 states and the four sample categories (M, F, Md, NMd), a spreadsheet of 108 cells was generated. As the sample size of the state of Paraná did not reach the response rates of PISA (INEP, 2016) and in the variables evaluated in this study, it was removed from the analysis, leaving 104 cells. The results were presented descriptively in measures of central tendency and dispersion and analyzed by Pearson's correlation test with the statistical program International Business Machines Statistical Package for the Social Sciences (IBM SPSS) version 23.0 for Windows.

For the path analysis, conducted by the statistical program Analysis of Moment Structures (IBM SPSS AMOS), the theoretical model adopted was the one that considers that phenomena that occur in the family environment precede those that occur in the educational environment. The variables related to the "family" aspect (HOMEPOS and EMOSUPS), therefore, were defined as independent or predictive variables. The variables ANX and BELONG (aspects "student" and "school") were used in the model as mediating variables. The dependent variables, that is, those that will be explained by the complete model, including the predictor and mediator variables, are the performances in mathematics (MATH), reading (READ) and sciences (SCIE). 


\section{Results}

The model demonstrated quality of fit between the variables, and this guarantees reliable results. For an excellent fit, the value of the chi-square test must be less than $20\left(\chi^{2} / \mathrm{df}<2\right)$ and the value of 0.129 was obtained; in perfect fit, the Comparative Fit Index must be greater than 0.9 (CFI> 0.9), in this study the value was 1.00; and the value of Root Mean Square Error of Approximation (RMSEA) must be less than 0.10 (Hair, Black, Babin, Anderson \& Tatham, 2009); in the present study the value was 0.001 .

Table 1 shows the descriptive statistics and results of correlation tests, with the magnitudes interpreted according to Cohen (1988), between the performance variables (MATH, READ, SCIE), and the variables "family" (EMOSUPS and HOMEPOS), "school" (BELONG), and "student" (ANX). The averages of the learning context variables are based on indexes constructed from information obtained internationally from the application of PISA.

The feeling of anxiety when taking school tests (ANX) was significantly correlated, in a moderate value, with reading performance (READ). The feeling of belonging to the school (BELONG) was not significantly correlated with the feeling of anxiety when performing tests (ANX) and was highly and positively correlated with the performances in the three subjects (READ, MATH, SCIE), and in a moderate way with emotional support and home environment (EMOSUP and HOMEPOS). The variables of "family" (EMOSUP and HOMEPOS) correlated moderate, positive, and significantly with each other. The measure of parental educational practices (EMOSUPS) correlated positively and significantly with the performances in the three disciplines (MATH, READ, SCIE), with great magnitudes. Parental emotional support (EMOSUPS) has also been correlated in a moderate and high, positive and significant way with the mediating variables ANX and BELONG, respectively.

The predictor variable that measured educational and cultural resources in the home (HOMEPOS) correlated positively and significantly, and with great magnitude, with the performances in the three disciplines in high correlations (MATH, READ, SCIE). HOMEPOS also has a moderate positive correlation with BELONG, but not with ANX, of the "student" aspect. The performances in the disciplines are presented in average scores calculated according to the plausible values method previously reported. Among the three scores, the highest mean was in READ, followed by SCIE and distant 24 points of MATH, which was the lowest mean.

Following are the path analysis in figures in which the arrows represent the impact that one variable has on the other $(\beta)$. The complete model can explain $70 \%$ of the variation in performance in mathematics (MATH) (Figure 1a), reading (READ) (Figure 1b) and $71 \%$ of performance in science (SCIE) (Figure 1c). The predictive variables of the context "family",

Table 1.

Mean values and standard deviations (SD) of the independent (VI), mediating (VM) and dependent (VD) variables and results of the correlation tests between the variables "performance in the disciplines" (READ, MATH, SCIE), "index of emotional support from parents"(EMOSUPS), "feeling of belonging to school"(BELONG), "educational and cultural resources index"(HOMEPOS) and "test anxiety index" (ANX).

\begin{tabular}{|c|c|c|c|c|c|c|c|c|c|}
\hline & & Mean & SD & EMOSUPS & HOMEPOS & BELONG & ANX & MATH & READ \\
\hline \multirow[t]{2}{*}{ VI } & EMOSUPS & -0.2 & 0.2 & & & & & & \\
\hline & HOMEPOS & -1.5 & 0.4 & $0.48 *$ & & & & & \\
\hline \multirow[t]{2}{*}{ VM } & BELONG & -0.2 & 0.2 & $0.55 *$ & $0.50 *$ & & & & \\
\hline & ANX & 0.6 & 0.2 & $0.46 *$ & 0.66 & 0.1 & & & \\
\hline \multirow[t]{3}{*}{ VD } & MATH & 351.1 & 38.5 & $0.58 *$ & $0.74 *$ & $0.62 *$ & -0.19 & & \\
\hline & READ & 378.1 & 44.5 & $0.68 *$ & $0.67 *$ & $0.68 *$ & $0.36 *$ & $0.88 *$ & \\
\hline & SCIE & 375.1 & 38.5 & $0.63 *$ & $0.75 *$ & $0.64 *$ & 0.13 & $0.97 *$ & $0.95 *$ \\
\hline
\end{tabular}

Note. $\mathrm{N}=104$

$*$ Indicates significant correlations between variables $(\mathrm{p}<.05)$

Psico-USF, Bragança Paulista, v. 26, n. 1, p. 13-25, jan./mar. 2021 
EMOSUPS and HOMEPOS, are the ones that start the paths, followed by the mediating variables of "student" (ANX) and "school" (BELONG), and end with the dependent variables represented by the performances in mathematics (MATH), reading (READ) and science (SCIE).

Parental educational practices (EMOSUPS) have an impact on (a) the feeling of belonging to school (BELONG) $(\beta=0.40)$; (b) anxiety when performing tests (ANX) $(\beta=0.55)$; (c) reading performance (READ) $(\beta=0.25)$, mathematics (MATH) $(\beta=0.34)$ and sciences (SCIE) $(\beta=0.29)$. In other words, if the EMOSUPS index increased by, for example, 10 points; BELONG would increase 4.0 points; ANX would increase 5.5; READ performance would increase 5.5 points, MATH 3.4 points, and SCIE 2.9 points.

Educational resources and culture present in the home (HOMEPOS) have an impact (a) on the feeling of belonging to school (BELONG) $(\beta=0.31)$; (b) anxiety when performing tests (ANX) $(\beta=-0.19)$; (c) performance in mathematics (MATH) $(\beta=0.47)$, reading (READ) $(\beta=0.38)$ and science (SCIE) $(\beta=0.49)$. In other words, if the HOMEPOS index increased by, for example, 10 points, BELONG would increase by 3.1 points; ANX would decrease by almost 2.0 points; the performance in READ would increase 4.7 points, MATH 3.8 points, and SCIE 4.9 points.

The "student" aspect, represented by the degree of anxiety in performing tests (ANX) appears with an impact on the performances in mathematics (MATH), reading (READ) and science (SCIE), however, it can only be considered in reading (READ), with which it has a statistically significant correlation. The impact of ANX in READ is $\beta=0.17$, that is, if the ANX index increased by, for example, 10 points, it would increase 1.7 points in READ.

The "school" aspect, represented by the feeling of belonging to the school (BELONG) has an impact on the performances in mathematics $(\mathrm{MATH})(\beta=$ $0.24)$, reading $(\mathrm{READ})(\beta=0.33)$ and science (SCIE) $(\beta=0.26)$, that is, if the BELONG index increased by, for example, 10 points, it would increase 3.3 points in READ, 2.4 in MATH and 2.6 in SCIE.

\section{Discussion}

In the light of developmental psychology, and in line with evolutionary and educational approaches, the learning context involves three main dimensions: student, school and family (SSF) (Bronfenbrenner \&
Morris, 1998). In this study, the "student" aspect was represented by the students' feeling of anxiety when performing tests (ANX), the "school" aspect by the student's sense of belonging in their school environment (BELONG), and the "family" aspect by two complementing variables: the environment offered by the family, in terms of parenting educational practices (EMOSUPS), and the educational and cultural resources existing in the home (HOMEPOS). It is understood that the phenomena related to the "student" and "school" aspects are influenced by the "family" aspect (Briley et al., 2018; Erbeli et al., 2018, Kong et al., 2018). The "school" appears later in the lives of individuals, and despite being the environment that introduces the contents that will be tested (Mendes et al., 2018), it does not guarantee success in the disciplines alone (Pizarro \& Junior, 2017). The demand for satisfactory school performance can lead to anxiety, which can be useful or harmful, depending on the level of this feeling (Gonzaga et al., 2017; Stein \& Neste, 2015; Steinmayr et al., 2016). Due to this overlapping of variables in regard to the student and their vision and feelings about their family, home, and school, and on their performance, EMOSUPS and HOMEPOS (family) were used as predictor variables, while ANX (student) and BELONG (school), as mediators of school performance.

It is worth mentioning that the reference index of the variables is zero; the negative values represent a lower degree and the positive values represent a higher degree in the variable in question. Countries belonging to the OECD, for example, have positive values and Latin American countries have negative values of HOMEPOS, that is, when compared to OECD countries, the participants in Latin American countries have less educational and cultural goods in their homes (INEP, 2016). In the present study, HOMEPOS, EMOSUPS and BELONG are negative. Students have less educational and cultural resources, less support from parents and feel little belonging to the school. The "student" aspect, represented by the variable anxiety when taking tests (ANX), presented a positive value, indicating that students feel more anxious when taking tests, when compared to countries in which this index is negative (e.g. Finland) (INEP, 2016).

Starting from the predictor variables, we noted that, as expected, the effect of the environment promoted by the family (EMOSUPS and HOMEPOS) correlates positively with each other and with the performance in all subjects. The effect of HOMEPOS, however, was 


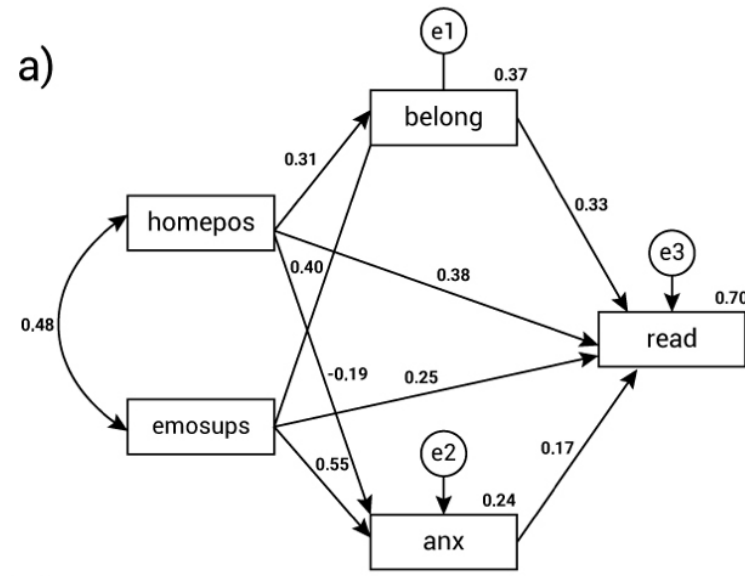

b)
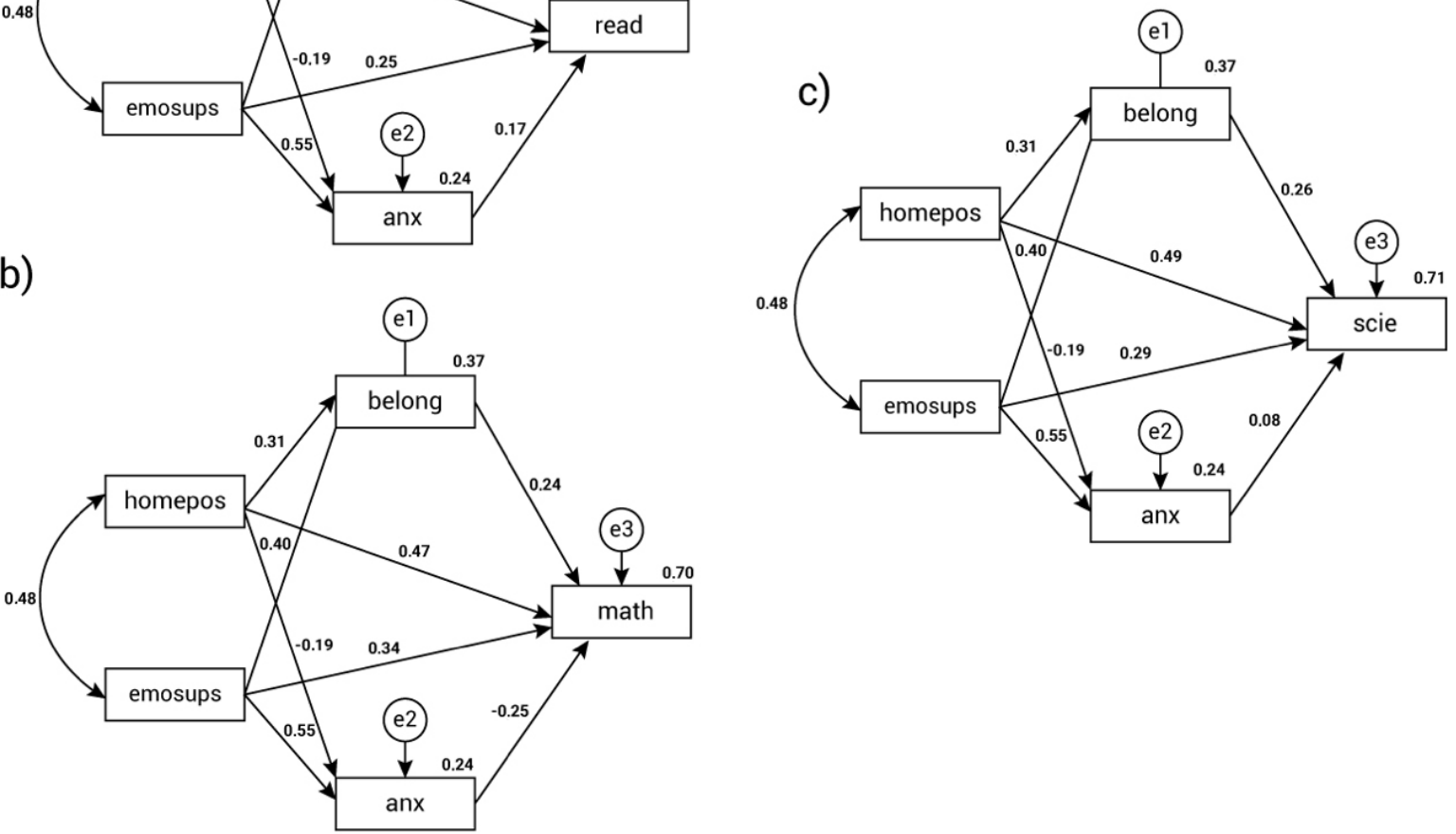

Figure 1. Representation of the trajectory analysis considering the predictor variables: educational and cultural resources (homepos) and emotional support from parents (emosups), and mediating variables: feeling of belonging to the school (belong) and degree of anxiety when taking tests (anx), in explaining the performances in a) mathematics (math), b) reading (read) and c) sciences (scie). Generated by the AMOS SPSS extension program, the arrows represent the impact that one variable has on the other, measured by the test's $\beta$ value. The numbers above the rectangles represent $\mathrm{R}^{2}$, that is, the percentage of the variance explained by the previous variable; "e1; e2; e3" represent the effects external to the model, undetermined here, but whose effect was pointed out in the test.

greater $(r=0.74$; Table 1$)$ with MATH and SCIE (Table 1). The performance in math and science requires specific skills (e.g., quantitative and visuospatial) that may be better developed by environmental stimulation and recreational experiences, that were represented here by HOMEPOS, than with the assistance and monitoring of the parents (EMOSUP) (Halpern et al., 2007). The difference in the effect of HOMEPOS and EMOSUPS on performances did not contemplate READ, perhaps because this is a skill that can be developed simply by offering books or magazines, items that are easier for any student to access, and that can be enriched both by HOMEPOS and EMOSUPS.
Reading performance (READ) was the only variable correlated with anxiety when performing tests (ANX; $r=0.36$, Table 1). The greater the sense of anxiety self-reported by the students, the best performances they had in reading assessments. Moderate anxiety during school evaluations seems to compromise academic performance. In another sample of adolescents, Steinmayr et al. (2016) recorded lower school performance, considering the average of grades in the subjects, when the students' concern was greater, measured directly (and not self-reported), by a comprehensive inventory for measuring anxiety (German Test Anxiety Inventory). On the other hand, it is possible that reading tasks require 
more attention and preparation from students, which make them feel anxiety more sharply (Stein \& Neste, 2015). Social and cultural pressure seems to impose on students a need to do well in tests, giving tests an anxiogenic character (Gonzaga et al., 2017). The sense of anxiety (ANX) had positive impact $(\beta=0,17)$ in READ (Figure 1b), suggesting that the feeling of anxiety reported may lead to bigger and better preparation for assessments in reading, rather than compromise their performance.

Science performance (SCIE) is affected differently by EMOSUPS and HOMEPOS, reaching a distance of 20 points (Figure 1c). In other words, more than feeling supported and motivated by the parents (Baharudin et al., 2010; Wang et al., 2014), having diverse sources of information at home, as well as favorable environments for concentration and study without distractors, has a greater effect on performance, especially in science, but also in mathematics and reading (MATH and READ). This result is in accordance with findings that demonstrate the positive effects arising from the family, but emphasize the importance of the type of environment to accomplish better educational achievements (Alves et al., 2016; Baharudin et al., 2010; Castro et al., 2015).

The strongest impact of HOMEPOS on performance in mathematics $(\beta=0.47)$, reading $(\beta=0.38)$ and science $(\beta=0.49)$, (Figures $1 \mathrm{a}, 1 \mathrm{~b}$ and $1 \mathrm{c}$, respectively) corroborates the arguments that socioeconomic status explains part of the academic achievement (Lynn et al., 2017). Although the choice of this variable was made in an attempt to remove other variables related to income, it is noted in its description, that several items, even those considered educational resources, are easier to obtain with a higher income (such as computers and access to the internet). Nonetheless, the variable includes items related to the home routine, the family's upbringing style and coexistence (e.g., a table and quiet place to study); and there are also items related to culture (e.g., musical instruments and works of art) and to the level of education (e.g., literature books and technical books). It is likely that the results involving this variable were stronger precisely because it is a comprehensive variable and has an effect on the others: families that are more aware of the importance of their children's cognitive development and educational achievement, both directly support them and create in their homes and routines, moments and environments proper for this.

The positive relationship between HOMEPOS with EMOSUPS and HOMEPOS with BELONG
(Table 1) suggests that these aspects are related in the lives of adolescents. Amongst these variables, the way students perceive the family's emotional support (EMOSUPS) is significantly correlated with ANX ( $r=$ 0.46; Table 1). EMOSUPS has a considerable positive impact on ANX $(\beta=0.55)$ and HOMEPOS has a negative impact $(\beta=-0.19)$ on this measure (Figure 1). The absence of a BELONG and ANX correlation indicates that the feeling of anxiety among young people in relation to school tests occurs regardless of whether young people feel they belong to the school environment or not. The correlation and positive impact of the family's emotional support in relation to the feeling of anxiety when students take tests - the greater the emotional support, the greater the feeling of anxiety - would be expected for negative educational parenting practices (Gomide, 2014; Sapienza et al., 2009). However, it can be explained in ways such as: the emotional support of parents and family members is accompanied by anxious behaviors on their part, reflecting anxiety in their children as well (Stein \& Nessa, 2015); or even in the unintentional parental reinforcement with demonstrations of excessive concern and anxiety in relation to their children, when facing school evaluations (Briley et al., 2018). When at risk (implicit threat of, for example, school failure, parental punishment, feelings of intellectual failure and social exclusion), young people are likely to exhibit fear, distrust and alert behaviors that are activated at the same time as attachment behaviors (Ainsworth et al., 2015). In contrast, the effect of HOMEPOS on ANX demonstrates that a home that fosters education and culture, probably generating wellbeing (Steinmayr et al., 2016), seems to decrease anxiety.

The predictor variables HOMEPOS and EMOSUPS correlated positively with the mediator variable BELONG (Table 1$)$ and had a positive impact $(\beta=$ 0.31 and 0.40 , respectively; Figure 1$)$ : the more students reported feeling supported and motivated by family and having information sources available and a quiet place to study, the more they declared feelings of belonging to school. Young people who feel integrated and safe at home and in the family tend to increase their exploratory behaviors (Ainsworth et al., 2015; Bjorklund \& Pellegrini, 2002), thus increasing the possibilities of new associations and belonging to new groups, such as relationships in a school or classroom environment. These associations can be the relationships they establish in their school environment, where they form new social groups to which they feel they belong. The type of family interaction also contributes to the way 
individuals position themselves before the group, promoting or hindering contact possibilities (Fogaça et al., 2019). These results point to the importance of family experiences that promote a sense of security in their children and the resources needed so they can deal with school experiences. Different learning experiences take place in the different microsystems in which the individual participates, interacting and adding to each other (Bronfenbrenner \& Morris, 1988).

The need to form social groups was not always the same as that found in today's society. In ancestral societies groups were smaller and established by shared functions and mutual cooperation that offered advantages, today they are huge and usually created by convenient spatial circumstances, such as the school (Tooby \& Cosmides, 1989). The convenience in grouping, however, does not exclude the benefits of mutual support. Students in a Portuguese primary school, that received support from colleagues, even when there was no demonstration of affection, performed better in Portuguese and mathematics (Mendes et al., 2018). In this study, the more the students felt they belonged to the school, the more dedicated they were to it and the better their performances were (Table 1).

At proximal level, school socialization is initiated by communication between family and children about academic expectations and the value of education. The discussion of learning strategies constitutes positive parenting practices that involve the family in the adolescent's school life and that seem to be critical variables for the student's well-being and school success (Bolsoni-Silva \& Fogaça, 2018; Gomide, 2014). The psychological mechanism behind this success must be in the motivation and in the development of autonomy to pursue and achieve goals (Hill \& Tyson, 2009), coming mainly from the monitoring of parents or guardians.

We have presented in this study a model of analysis using appropriate statistical indicators and consistent in theory. This does not mean that the model is perfect, unique or conclusive. It is possible that other models also explain the phenomena analyzed here. However, it seems essential that the learning context is seen as formed simultaneously by the aspects "student, school and family". The context of learning, analyzed jointly and with a sample representative of Brazil was able to explain $70 \%$ of the variation in mathematics and reading performance (Figures $1 \mathrm{a}$ and $1 \mathrm{~b}$ ) and $71 \%$ of the performance in science (Figure 1c). The trajectory analysis provided a visualization of the reciprocating relationships and the effects of one variable on the other, offering an understanding of the phenomena within the context of three-dimensional learning.

All variables were reported by the students themselves, which can be a limitation of this study. Other ways of capturing this data would involve student diagnoses, observations on the school climate and responses from families and other members of the school community. Future studies may use other data to analyze the learning context. However, we recommend the use of PISA data in its 2018 edition as the source of this information and the sequence to the study, including comparisons between years and samples.

The academic performance of young people is not simply produced during school years or during testing. It is influenced by social mechanisms in levels of complex and diverse relations, and must be taken into account in the elaboration of public policies in the area of education. Any improvement that leads to personal fulfillment will have an impact on school success and on the future of young people and their community (Curi \& Menezes-Filho, 2014; Lynn et al., 2017). Having housing and being matriculated in school is not enough for the learning context to be efficient. There must be quality in these environments. This information should reach not only the public authorities, but also the families and the entire school community, who are the subjects possibly forming bonds with young Brazilian students. They are the ones who will promote a welcoming environment and collaborate for personal well-being. The mutual relationships between variables in the three dimensions indicate that any aspect of the learning context can feed back to another: the school, the student; the family, the student; the student, the school, and so on. The actions initiated in the school, such as cultural fairs and encouraging reading programs may influence the families to promote domestic environments with more resources, resulting in real benefits to students.

\section{References}

Ainsworth, M. D. S., Blehar, M. C., Waters, E., \& Wall, S. N. (2015). Patterns of attachment: A psychological study of the strange situation (Classic Edition). New York: Psychology Press.

Alves, A. F., Lemos, G. C., Brito, L., Martins, A. A., \& Almeida, L. S. (2016). Desempenho cognitivo na infância: a mãe e o meio urbano fazem a diferença. Psicologia: teoria e pesquisa, 32(3), 1-9. doi: 10.1590/0102-3772e323217 
Baharudin, R., Hong, C. Y., Lim, S. J., \& Zulkefly, N. S. (2010). Educational goals, parenting practices and adolescents' academic achievement. Asian Social Science, 6 (12), 144-152. doi: 10.5539/ass.v6n12p144

Bjorklund, D. F., \& Pellegrini, A. D. (2002). The origins of human nature: Evolutionary developmental psychology. American Psychological Association. doi: 10.1037/10425-000

Bolsoni-Silva, A. T., \& Fogaça, F. F. S. (2018). Promove-Pais: Treinamento de habilidades sociais educativas: Guia teórico e prático. São Paulo: Hogrefe/Cetepp.

Briley, D. A., Livengood, J., Derringer, J., Tucker-Drob, E. M., Fraley, R. C., \& Roberts, B. W. (2018). Interpreting Behavior Genetic Models: Seven Developmental Processes to Understand. Behavior genetics, 49 (2) 196-210. Retrieved from https:/ / link. springer.com/article/10.1007/s10519-018-9939-6

Bronfenbrenner, U.; Morris, P. A. (1998). The ecology of developmental processes. In: Damon, W.; Lerner, R. M. (Orgs.), Handbook of child psychology: Theoretical models of human development (pp. 9931028). New York: John Wiley.

Cabrera García, V. E., Aya Gómez, V. L., Muñoz Gómez, D. S., Guevara Marín, I. P., \& Cano Rodas, A. M. (2016). Madres, padres y profesores como educadores de la resiliencia en niños colombianos. Psicologia escolar e educacional, 20(3), 569-579. doi: 10.1590/2175-3539201502031049

Campos, J. R., Silva, A. T. B., Zanini, M. R. G. C. \& Loureiro, S. R. (2019). Preditores de problemas comportamentais em adolescentes: variáveis familiares, pessoais e demográficas. Psico-USF, 24(2), 273-285. doi: 10.1590/1413-82712019240205

Castro, M., Expósito-Casas, E., López-Martín, E., Lizasoain, L., Navarro Asencio, E., \& Gaviria, J. L. (2015). Parental involvement on student achievement: A meta-analysis. Educational Research Review, 14, 33-46. doi: 10.1016/j.edurev.2015.01.002

Cohen, J. (1988). Statistical power analysis for the behavioral sciences. Hillsdale, NJ, Erlbaum.

Cole, M. \& Cole, SR (2004). O desenvolvimento da criança e do adolescente. Porto Alegre: Artmed.

Curi, A.Z., \& Menezes-Filho, N. (2014). The relationship between school performance and future wages in Brazil. Economia, 15(3), 261-274. doi: 10.1016/j. econ.2014.08.001
Dessotti, E., \& Dessotti, I.C.C. (2015). A escola serve ou tem serventia? Uma análise da proposta do estado de São Paulo sob o olhar do neoliberalismo. Laplage em Revista, 1(2), 132-140. doi: 10.24115/ S2446-622020151226p

Erbeli, F., Hart, S. A., \& Taylor, J. (2018). Genetic and Environmental Influences on Achievement Outcomes Based on Family History of Learning Disabilities Status. Journal of learning disabilities, 52(2), 135-145. doi: 10.1177/0022219418775116

Fernández, Ríos, \& Marques (2016). El lenguaje como factor de desigualdad en los aprendizajes en Pisa 2009: El caso de la frontera noreste de Uruguay con Brasil. Civitas - Revista de Ciências Sociais, 16(1), 119-135. doi: 10.15448/1984-7289.2016.1.24239

Fogaça, F. F. S., Tatmatsu, D., Comodo, C. N., Del Prette, Z. A. P., \& Del Prette, A. (2019). O Desenvolvimento de habilidades sociais na adolescência como ápice comportamental. Revista Brasileira de Terapia Comportamental e Cognitiva, 21(2), 217-231. doi: 10.31505/rbtcc.v21i2.1162

Gomide, P. I. C. (2014). Inventário de Estilos Parentais IEP: Modelo teórico, manual de aplicação, apuração e interpretação. Petrópolis, RJ: Vozes.

Gonzaga, L. R. V., da Silva, A. M. B., \& Enumo, S. R. F. (2016). Ansiedade de provas em estudantes do Ensino Médio. Psicologia Argumento, 34(84), 76-88. doi: 10.7213/psicol.argum.34.084.AO07

Hair, J. F., Black, W. C., Babin, B. J., Anderson, R. E., \& Tatham, R. L. (2009). Análise multivariada de dados [Multivariate Data Analysis]. Bookman Editora.

Halpern, D. F., Benbow, C. P., Geary, D. C., Gur, R. C., Hyde, J. S., \& Gernsbacher, M. A. (2007). The science of sex differences in science and mathematics. Psychological science in the public interest, 8(1), 1-51. doi: 10.1111/j.1529-1006.2007.00032.x

Hill, N. E., \& Tyson, D. F. (2009). Parental involvement in middle school: A meta-analytic assessment of the strategies that promote achievement. Developmental Psychology, 45, 740-763. doi: 10.1037/ a0015362

Instituto Nacional de Estudos e Pesquisas Educacionais Anísio Teixeira - INEP (2016). Brasil no PIS A 2015: Análises e reflexões sobre o desempenho dos estudantes brasileiros/OCDE-Organização para a Cooperação 
e Desenvolvimento Econômico. São Paulo: Fundação Santillana.

Kong, A., Thorleifsson, G., Frigge, M. L., Vilhjalmsson, B. J., Young, A. I., Thorgeirsson, T. E., ... \& Gudbjartsson, D. F. (2018). The nature of nurture: Effects of parental genotypes. Science, 359(6374), 424-428. doi: 10.1126/science.aan6877.

Lynn, R., Antonelli-Ponti, M., Mazzei, R. F., Da Silva, J. A., \& Meisenberg, G. (2017). Differences in intelligence and socio-economic outcomes across the twenty seven states of Brazil. Mankind Quarterly, 57(4), 519-541. Recuperado de http://www. mankindquarterly.org/archive/issue/57-4/3.

Macarini, S.M., Martins, G.D.F., Minetto, M. F. J., \& Vieira, M.L. (2010). Práticas parentais: Uma revisão da literatura brasileira. Arquivos Brasileiros de Psicologia, 62(1), 119-134. Retrieved from https:// www.redalyc.org/articulo.oa?id=229016557013

Melo, S.G. (2017). Relação entre clima escolar e desempenho acadêmico em escolas públicas de ensino médio representativas de um estado brasileiro (Dissertação de Mestrado). Universidade Estadual Paulista, Marília, São Paulo, SP, Brasil.

Mendes, R.C., Nascimento, D., \& Costa-Lobo, C. (2018). Efeitos do Programa Apoio Curricular Entre Pares na Autoeficácia Percebida, na Afetividade e no Rendimento. Meta: Avaliação, 10(28), 1-28. Retrieved from https://pdfs.semanticscholar.org/ 9cbd/97330f7713f0c55edb35f340fdf98813aab3. pdf.

Miranda, P. V., Pereira, A. S., \& Rissetti, G. (2016). A influencia do ambiente escolar no processo de aprendiragem de escolas técnicas. Seminário Nacional de Pesquisa em Educação. Retrieved from file:///C:/Users/ Arnaldo/Downloads/14918-11921-1-PB.pdf.

Pezzi, F. A. S., Marin, A. H. (2017). Fracasso escolar na educação básica: Revisão Sistemática da Literatura. Temas em Psicologia, 25(1), 1-15. doi: 10.9788/ TP2017.1-01.

Pizarro, M. V., \& Junior, J. L. (2017). Os sistemas de avaliação em larga escala e seus resultados: $O$ PISA e suas possíveis implicações para o ensino de ciências. Ensaio Pesquisa em Educação em Ciências, 19, 1-24. doi: 10.1590/1983-21172017190119.

Prates, K., Lima, C.R., \& Ciasca, S. M. (2016). Estratégias de aprendizagem e sua relação com o desempenho escolar em crianças do Ensino Fundamental I. Revista Psicopedagogia, 33(100), 19-27. Retrieved from http://pepsic.bvsalud.org/pdf/ psicoped/v33n100/03.pdf.

Sapienza, G., Aznar-Farias, M., \& Silvares, E. F. M. (2009). Competência social e práticas educativas parentais em adolescentes com alto e baixo rendimento acadêmico. Psicologia Reflexão e Crítica, 22(2), 208-213. doi: 10.1590/S0102-79722009000200006.

Silva, CM, Constantino, EP e Rondini, CA (2012). Família, adolescência e estilos parentais. Estudos de Psicologia (Campinas), 29(2), 221-230. doi: 10.1590/ S0103-166X2012000200008.

Stein, D. J., \& Nesse, R. M. (2015). Normal and abnormal anxiety in the age of DSM-5 and ICD-11. Emotion Review, 7(3), 223-229. doi: $10.1177 / 1754073915575407$.

Steinmayr, R., Crede, J., McElvany, N., \& Wirthwein, L. (2016). Subjective well-being, test anxiety, academic achievement: Testing for reciprocal effects. Frontiers in psychology, 6. doi:10.3389/fpsyg.2015.01994

Taylor, Z.E., Conger, R. D., Robins, R.W. \& Widaman, K. ( 2015). Parenting practices and perceived social support: Longitudinal relations with the social competence of mexican-origin children. Journal of Latina/o Psychology, 3(4), 193-208. doi: 10.1037/ lat0000038

Tooby, J., \& Cosmides, L. (1989). Evolutionary psychology and the generation of culture, part I: Theoretical considerations. Ethology and sociobiology, 10(1-3), 2949. doi: 10.1016/0162-3095(89)90012-5

Wang, M.T., \& Sheikh-Khalil S. (2014). Does parental involvement matter for student achievement and mental health in high school? Child Development, 85(2), 610-625. doi: doi.org/10.1111/cdev.12153

Recebido em: 23/01/2019

Reformulado em: 29/01/2020

Aprovado em: 18/03/2020 
Acknowledgments:

We appreciate the promptness of Professor José Egidio Barbosa Oliveira (Universidade de Luxemburgo) to indicate ways of statistical analysis and also the availability of the colleague Vinicius Peres (Universidade de São Paulo) to grant his skills to draw the figures.

About the authors:

Mayra Antonelli-Ponti is a biologist, Master and Doctor of Sciences with focus on Psychobiology at the Universidade de São Paulo. Her researches are in the areas of evolutionary psychology, genetics of human behavior and social psychology, always with a focus on educational issues. She collaborates with the Laboratório de Estudos e Pesquisas em Economia Social (Laboratory of Studies and Research on Social Economy, LEPES - USP), at assessing the implementation of educational programmes. She's a part of the group of scientific divulgation PsicoBio em Rede (PBR), through which teacher training courses are offered.

ORCID: https://orcid.org/0000-0003-4931-2788

E-mail: antonelli.may@usp.br

Patrícia Ferreira Monticelli is a biologist, Doctor of Sciences by the Post-Graduation Program in Experimental Psychology (Neurosciences and Behavior) of the Universidade de São Paulo, SP, and with a post-doctorate in experimental psychology, IPUSP/SP. She is a teacher at the psychology department of FFCLRP, in Ribeirão Preto, where she coordinates the Laboratório de Etiologia e Bioacústica (Laboratory of Ethology and Bioacoustic) and supervises students through PPG Psicobiologia. Her lines of research include parental and educational matters investigated in the light of evolutionary psychology.

ORCID: https://orcid.org/0000-0002-9546-4160

E-mail:monticel@usp.br

Fabiana Maris Versuti is a psychologist, Doctor in Education for Science by UNESP/Bauru with a post-doctorate in education by USP/FFCLRP. She is a teacher in the Psychology department at FFCLRP, in Ribeirão Preto, responsible for the disciplines Psychological Foundations of Education and Teaching Sciences, co-responsible for the Laboratory of Studies and Interventions on Socio-emotional and Career Development. She is an accredited supervisor at PPG Psicobiologia. She coordinates the Licentiate in Sciences Degree at the Universidade de São Paulo - Campus Ribeirão Preto

ORCID: https://orcid.org/0000-0001-8974-3537

E-mail: fabiana_versuti@usp.br

Josiane Rosa Campos is a clinical psychologist at the Instituto de Análise do Comportamento (Institute of Behavior Analysis) in Ribeirão Preto and is one of the creators of Ser Educativo-Instituto de Habilidades Socioemocionais (Institute of Socio-emotional abilities), where she works as university teacher and preventive psychologist. She graduated from UNESP/Bauru, is Doctor in psychology by UFSCar and has a post-doctorate in developmental and learning psychology by UNESP/Bauru.Her research themes include the academic performance, parentak educational practices, social abilities, social competence, socio-demographic variables and adolescents' internalizing and externalizing behavior issues.

ORCID: https://orcid.org/0000-0001-5825-1134

E-mail: josirosacampos@gmail.com 
Luciana Carla dos Santos Elias is a psychologist, graduated from USP/FFCLRP, with enhancement in psychopedagogy and specialized in learning difficulties by the Hospital das Clínicas at USP/FMRP. She is a doctor in psychology by FFCLRP, teacher at the psychology department and supervisor at PPG Psicologia at FFCLRP. She coordinates the Laboratório de Psicologia da Educação e Escolar (Laboratory of Education and School Psychology - LAPEES), developing researches concerning social abilities, inclusion of students in the public education system and school psychology. She is a member of the editorial council of Revista Paidéia and current president of the Center of Research and Applied Psychology of FFCLRP.

ORCID: https:/ / orcid.org/0000-0002-1623-06744

E-mail:lucaelias@ffclrp.usp.br

\section{Contact:}

Departamento de Psicologia da Faculdade de Filosofia, Ciências e Letras de Ribeirão Preto Av. Bandeirantes, 3900, Monte Alegre

Ribeirão Preto-SP, Brasil

CEP: $14040-901$ 